\title{
Learnings from Sustainability Audits in Automobile Industry in Around Pune: Practices and Procedures
}

\author{
Shilpa Kulkarni, C.N.Rawal
}

\begin{abstract}
The sustainability is now considered as a paradigm shift. Challenging business environments, less availability of resources and much more competitive markets force business to rethink about the offerings in order to sustain for a greater time. Organizations across the globe are tending to apply many sustainability measures in order to make the business balance and holistic. The audit of such sustainability-oriented efforts is done by various methods like Carbon Credits, Dow Jones sustainability index etc. The most popular method of audits is Global Reporting Initiative (GRI). GRI evaluates the organization on all the three Aspects-Economic, Environmental and Social sustainability. The research papers discuss the sustainability audits in light of Automobile sector and also furnishes the analogy between the efforts of the five passenger vehicle Manufacturing Units (PVMU) reports. The research paper discussed the similarity between social engineering, environmental measures and economic impacts. The final conclusion suggests that global companies do not have localize approach of sustainability whereas Indian organizations lack the global viewpoints in accepting new technologies.
\end{abstract}

Keywords: Sustainability Audits. GRI, Automobile industry.

\section{INTRODUCTION}

The main objective of sustainability is to satisfy human needs that last. Organization functions on capital, people and natural resources. It is essential that the business processes should be designed to maintain sustainable resources even for future generations. Corporate sustainability generally refers to the business processes, which have the inclusion of social and environmental concerns and engagement of stakeholders The concept of corporate sustainability originates from the wider concept of sustainability, which itself was formed through a number of political, public and academic impacts over time (Kidd, 1992).

As per World Commission on Environment and Development (WCED) definitions and prior research literature, the corporate sustainability is more ecologically inclined (Shrivastava, 1995) or either social responsibility of an organization (Carroll, 1979) or broaden the concept of corporate sustainability to integrate corporate economic activities with organizational concern about the natural and the social environment (Griffiths \& Zammuto,2005)

Corporate sustainability could be defined in the following ways (Dyllick \& Hockerts, 2002).

Revised Manuscript Received on March 2, 2020.

* Correspondence Author

Dr.Shilpa Kulkarni*, Research Co-ordinator, Brihan Maharashtra College of Commerce, Pune .India hrshilpak@gmail.com

Dr.C.N.Rawal, Principal, Brihan Maharashrta College of Commerce, Pune, India.cnr18@gmail.com
A) Sustainable organization's actions are economically and socially yet environmentally interdependent.

B) Stakeholders are considered in the long term as well as short-term strategies.

C) The sustainable organization does not thrive on capital invested but generates capital.

Sustainable organization includes an environmental and social aspect of the strategy. When congruence of environmental, social and economic goals happens, the overall performance of a business will not only be based on financial results but also by its environmental and social performance (Steimle \& Zink, 2006).

\section{LITERATURE REVIEW}

The sustainability is vast concept and yet less researched. The basic definition of sustainabile Development is adopted from Brundtland Report - "Our Common Future" in 1987

"Sustainable development is development that meets the needs of the present without compromising the ability of future generations to meet their own needs."

Corporate Sustainability as Economic Sustainability In earlier research, the term corporate sustainability was pointing to long-term profitable investments, growth in term on monetary values (Porter, 1985; Daly, 1987; Peteraf, 1993). The core concept of this assumption is business is means to increase the wealth of the investor (Fowler \& Hope, 2007). Therefore, it is implied that business will gain a larger market share by an increase in the sale of products or services. Social or ecological investments are generally discouraged as they are seen as a cost center (Levitt, 1958; Friedman, 1970; Barbier, 1987; White, 1996). Although many studies have shown that ecological investment yields better result even in economic terms.

\section{Corporate Sustainability as Environmental} Sustainability

Environmental sustainability is vital for any business, as lack of environmental sustainability will affect business prospects, as business is a part of the ecosystem in which it works (Percy,2000; Sharma, 2003). Waste management, management of resources, such as energy and water are key the business activity with a direct impact on ecological sustainability. Any malpractice in these areas shows a negative impact on the business (Post \& Altmann 1994; Christmann et al., 1999; Pojasek ,2000; Sutton, 2000).

Environmental quality influences business as seen in climate change, there is a need for radical shifts in 
approaches of business goals. (Hart, 1997; Shrivastava, 1995; Winn \& Kirchgeorg, 2005). Environmental sustainability should be more than just a compliance, with business focusing on resource minimization and consciously working towards ecological footprint (Hart, 1995; Banerjee, 2001; Sharma, 2003; Riordan et al., 2005; Morelli, 2011).

\section{Corporate Sustainability as Social Sustainability}

Business is run by stakeholders and for the stakeholders, and hence the goal of business should be an upliftment of the stakeholders, alternatively business should shoulder wider responsibilities towards various stakeholder groups and the social environment in which they operate (Carroll, 1979; Dunphy et al., 2007). Right from the industrial revolution social aspects of the business has been researched. (Carroll, 1979; Preston, 1985; Shrivastava, 1995, Shadur et al.,1999). In the recent time's terms like corporate social responsibility, business social responsibility has emerged. These terms either suggest organizations attention to internal employee development or stakeholder engagement or the dealing proactively with the community. ( Fernandez et al, 2003; Jenkins, 2005) Social sustainability can be defined as practices to ensure that the cohesion of society and its ability to work towards common goals are maintained. Individual needs such as those for health and well-being, nutrition, shelter, education, and cultural expression should be met (Kidd, 1992; Brammer \& Millington, 2008; Johnston et al., 2011).

\section{Corporate Sustainability as a Holistic Approach}

The holistic approach suggests the combination of all the approaches of sustainability which is defined as a triple bottom line which refers to the planet(ecological), people(social) and profit (economical)as three evaluation perspectives (Elkington, 1997). The linking between the three perspectives is also echoed in the works of Dunphy et al., (2007), van Marrewijk (2003) and Young \& Tilley, (2006). For the organizations, it implies that the need of the balancing all the perspective i.e. adapting business practices which will reduce ecological footprint, improve social welfare and yet achieve economic success (Dyllick \& Hockerts, 2002; Bansal, 2005). However, few researchers adopted a broader approach, which proposes interrelations with their environments on various dimensions, such as the individual, organizational, political- economic, socio-cultural and ecological-environment levels (Starik \& Rands, 1995). The study hence focuses on a tripartite model for sustainability as it leads to a holistic approach.

\section{Corporate Sustainability Reporting}

Sustainability reporting is being recognized as a significant factor contributing to corporate sustainability (Cho et al., 2010, Lozano and Huisingh, 2011) The success is multidimensional attribute, as diverse set of stakeholders pursuing dissimilar economic, environmental, and social interests determine the success of an organization (Liverman et al., 1988; Buchholz and Rosenthal, 2005; Laplume et al., 2008). Earlier sustainability reporting was predominantly financial or economic sustainability as seen from financial reporting in 1970. It was later in the 1980s the social sustainability was also reported but not a major aspect. During the 1980s the environmental issues like climate change, waste generation was focused and hence it was seen that the business reporting also reflects the environmental sustainability. By 1990, many businesses started reporting economic success and environmental success jointly. Later this trend established into a voluntary disclosure framework like the Global Reporting Initiative (GRI) (Hahn \& Kuhnen, 2013). Although there is a standardized approach while reporting as per GRI organization tend to report in the different approach to same standards define in GRI guideline. Reporting is a very powerful tool than corporation communication. Moreover, Sharma et al., (2007) have suggested a framework regarding sustainability reporting, which is composed of three modules.

Table 1: Reporting Tools and Measures for Sustainability Initiatives

\begin{tabular}{|l|l|}
\hline \multicolumn{1}{|c|}{ Assessment tool } & \multicolumn{1}{c|}{ Measures for sustainable development } \\
\hline Dow Jones Sustainability Index & $\begin{array}{l}\text { Global indexes tracking the financial performance of the leading sustainability-driven } \\
\text { companies }\end{array}$ \\
\hline $\begin{array}{l}\text { Environmental Performance } \\
\text { Index }\end{array}$ & Measures performance in terms of environmental relative to the paths of other countries \\
\hline $\begin{array}{l}\text { Global Reporting Initiative } \\
\text { (GRI) }\end{array}$ & $\begin{array}{l}\text { Inclusive framework for ecological footprint reporting, environmental social governance } \\
\text { (ESG) reporting, triple bottom line (TBL) reporting, and corporate social responsibility } \\
\text { (CSR) reporting. }\end{array}$ \\
\hline Equator Principles & Risk management framework for Financial institutions \\
\hline
\end{tabular}

Source: Bell and Morse, (2008); Hahn and Kuhnen, (2013)

The overall reporting system will have an annual report, social report and environmental report. The integrated information system will then formulate the integrated report based on the key performance indicators of the corporate sustainability.

\section{The Triple Bottom Line}

The term triple bottom line was coined by Elkington, (1997)'s Cannibals with Forks: The Triple Bottom Line of 21st Century Business Line. This term got instant popularity as it is simple and refers to economic 
environmental and social indicators, which integrate with a reporting system. (Deal \& Kennedy, 1982). The term triple bottom line can be defined as a narrow term well as a broad term. Whenever the assessment of the economic, social and environmental indicators is time specific, the term is expressed in the narrow sense, on the other hand when the long-term change in the organizational values, strategies, and practices is assessed then the term is expressed in a broader sense.

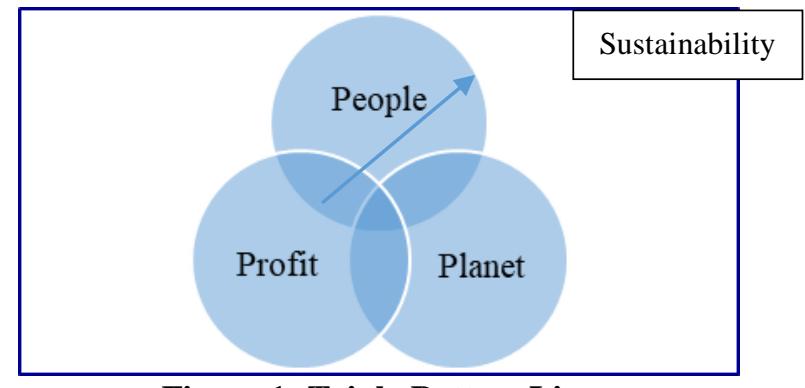

\section{Source: Elkington (1997)}

"The three lines represent society, the economy, and the environment. Society depends on the economy and the economy depends on the global ecosystem. The health of the global ecosystem represents the ultimate bottom line."

The report is an answer to audience questions (Hahn \& Kuhnen, 2013). Businesses are studied by customers, shareholders, academia and journalists and it is hence important to find a suitable approach for reporting. The strategy to publish a sustainability report relies on transparency with the specific requirement of a sustainability report. A typical sustainability report based on GRI is transparent and emphases on stakeholder engagement. The sustainability report, which is prepared, based on GRI standards, tries to answer the stakeholder's questions on sustainability initiatives and goals.

Sustainability reporting is being recognized as a significant factor contributing to corporate sustainability (Cho et al., 2010, Lozano and Huisingh, 2011) The success is multidimensional attribute, as diverse set of stakeholders pursuing dissimilar economic, environmental, and social interests determine the success of an organization (Liverman et al., 1988; Buchholz and Rosenthal, 2005; Laplume et al., 2008). Earlier sustainability reporting was predominantly financial or economic sustainability as seen from financial reporting in 1970. It was later in the 1980s the social sustainability was also reported but not a major aspect. During the 1980s the environmental issues like climate change, waste generation was focused and hence it was seen that the business reporting also reflects the environmental sustainability. By 1990, many businesses started reporting economic success and environmental success jointly. Later this trend established into a voluntary disclosure framework like the Global Reporting Initiative (GRI) (Hahn \& Kuhnen, 2013). Although there is a standardized approach while reporting as per GRI organization tend to report in the different approach to same standards define in GRI guideline. Reporting is a very powerful tool than corporation communication. Moreover, Sharma et al., (2007) have suggested a framework regarding sustainability reporting, which is composed of three modules.
Figure 1: Triple Bottom Line

The overall reporting system will have an annual report, social report and environmental report. The integrated information system will then formulate the integrated report based on the key performance indicators of the corporate sustainability.

\section{Research Methodology}

The research paper studies the sustainability reports of the five organizations in consideration. The reports are as per GRI framework. The objective of analysis to understand the key parameters of the sustainability in the passenger vehicle-manufacturing units. The detailed content study resulted into a comparative analysis of the sustainability initiative and the overall reporting quality.

The framework for analysis discussed ahead in the section. As the organizations are having global presence, the reports were reflecting the global viewpoint and challenges for the organizations. The study indicative measures for economic (profit), environmental (planet) and social parameters (people) interpreted the thought behind sustainability journey for the organization.

\section{Analysis of Sustainability Reports}

The GRI framework for standard has more than 100 indicators. For the analysis of the report, the focus will be mainly on the economic (profit), environmental (planet) and social (planet) indicators (GRI, 2006). The next section presents a matrix of the indicators and reporting organizations. The listed indicators are from GRI reporting standards. The method of analysis is adapted from the earlier by Dubravka (2017). In his work, he has done a content analysis using economic, social and environmental parameters and the sustainability reports of five cement organizations. As the study requires a deep understanding of the sustainability reports a detailed analysis is done using the matrix proposed by earlier researcher.

The three main aspects of GRI report economic, environmental and social are further divided into indicators. The report may or may not address all the indicators. It is interesting to observe the trend of disclosure in the organizations of the same industry. The sustainability reports of five organizations were considered for the study. There is only one indigenous firm in the research study, the rest are the joint venture or through foreign direct investments.

The reports are analysed and the observation is discussed in detailed in the further section. The GRI report of 2016-17 is considered for the study to maintain chronological consistency. The analysis starts with business economic aspect. The economic indicators are mapped across all the sustainability reports of 2015-16. Kindly note that * denotes the indicator is reported, NA denotes the indicator not available in the report and Out of scope denotes that the indicator is considered as out of boundary for the report by the organization.

\section{Economic Indicators}

The GRI standard has established code 200 for economic indicators.

There are total 13 standards under six economic 
Learnings from Sustainability Audits in Automobile Industry in Around Pune: Practices and Procedures

indicators. The organizations considered for the study PVMU 1, PVMU 2, PVMU 3, PVMU 4 \& PVMU 5 have the sustainability report based on G4 or GRI standard. G4 is compatible to GRI standard (Dubravka K., 2017).
The table depicts the comparative analysis of the sustainability reports and the key aspects of the profit related issues in sustainability report. These are captured separately in sustainability report snapshot of each organization. Refer annexure 1 for detailed GRI standards.

Table 2: Comparative Analysis of Economic Indicators

\begin{tabular}{|c|c|c|c|c|c|c|}
\hline $\begin{array}{l}\text { CATEGORY } \\
\text { ECONOMIC }\end{array}$ & $\begin{array}{c}201 \\
\text { series }\end{array}$ & $\begin{array}{c}\text { PVMU } \\
1\end{array}$ & $\begin{array}{l}\text { PVMU } \\
2\end{array}$ & $\begin{array}{l}\text { PVMU } \\
\mathbf{3}\end{array}$ & $\begin{array}{l}\text { PVMU } \\
4\end{array}$ & PVMU 5 \\
\hline \multirow{4}{*}{$\begin{array}{l}\text { Economic } \\
\text { Performance }\end{array}$} & 201-1 & $*$ & $*$ & $*$ & $*$ & $*$ \\
\hline & 201-2 & * & * & * & $*$ & * \\
\hline & 201-3 & * & * & * & * & * \\
\hline & 201-4 & * & * & $*$ & $*$ & $*$ \\
\hline \multirow{2}{*}{$\begin{array}{l}\text { Market } \\
\text { Presence }\end{array}$} & $202-1$ & NA & NA & NA & $*$ & NA \\
\hline & $202-2$ & NA & NA & NA & * & NA \\
\hline \multirow{2}{*}{$\begin{array}{l}\text { Indirect } \\
\text { Economic } \\
\text { Impacts }\end{array}$} & 203-1 & NA & NA & NA & $*$ & * \\
\hline & 203-2 & NA & NA & NA & $*$ & * \\
\hline $\begin{array}{l}\text { Procurement } \\
\text { Practices }\end{array}$ & 204-1 & $*$ & * & * & * & * \\
\hline \multirow{3}{*}{ Anti-corruption } & $205-1$ & $*$ & * & $*$ & $*$ & $*$ \\
\hline & $205-2$ & $*$ & $*$ & * & $*$ & $*$ \\
\hline & $205-3$ & * & $*$ & $*$ & $*$ & $*$ \\
\hline $\begin{array}{l}\text { Anti-competitiv } \\
\text { e Behaviour }\end{array}$ & 206-1 & * & * & * & $*$ & $*$ \\
\hline
\end{tabular}

- Reported and NA : Not Available in report

\section{Social Indicators}

There are 40 standards for 19 social indicators. The series of standards starts with code 400 . The organizations are sensitized towards gender equality and employee welfare, health and safety. Few reports suggest the few indicators as out of scope. Most of the reports suggest excellent employee training and skill development programme.

Table 3: Comparative Analysis of Social Indicators

\begin{tabular}{|c|c|c|c|c|c|c|}
\hline $\begin{array}{l}\text { CATEGORY: } \\
\text { SOCIAL }\end{array}$ & 400 series & PVMU 1 & PVMU 2 & PVMU 3 & PVMU 4 & PVMU 5 \\
\hline \multirow{3}{*}{ Employment } & $401-1$ & $*$ & $*$ & $*$ & $*$ & $*$ \\
\hline & $401-2$ & $*$ & $*$ & $*$ & $*$ & $*$ \\
\hline & $401-3$ & $*$ & $*$ & $*$ & $*$ & $*$ \\
\hline $\begin{array}{l}\text { Labour/Management } \\
\text { Relations }\end{array}$ & $402-1$ & NA & $*$ & NA & $*$ & $*$ \\
\hline \multirow{6}{*}{$\begin{array}{l}\text { Occupational Health and } \\
\text { Safety }\end{array}$} & $403-1$ & $*$ & $*$ & $*$ & $*$ & $*$ \\
\hline & $403-2$ & $*$ & $*$ & $*$ & $*$ & $*$ \\
\hline & $403-3$ & $*$ & $*$ & $*$ & $*$ & $*$ \\
\hline & $403-4$ & $*$ & $*$ & $*$ & $*$ & $*$ \\
\hline & $403-5$ & $*$ & $*$ & $*$ & $*$ & $*$ \\
\hline & $403-6$ & $*$ & $*$ & $*$ & & \\
\hline
\end{tabular}




\begin{tabular}{|c|c|c|c|c|c|c|}
\hline $\begin{array}{l}\text { CATEGORY: } \\
\text { SOCIAL }\end{array}$ & 400 series & PVMU 1 & PVMU 2 & PVMU 3 & PVMU 4 & PVMU 5 \\
\hline & $403-7$ & $*$ & $*$ & $*$ & $*$ & $*$ \\
\hline & $403-8$ & $*$ & $*$ & $*$ & $*$ & * \\
\hline & $403-9$ & $*$ & $*$ & $*$ & $*$ & $*$ \\
\hline & 403-10 & $*$ & $*$ & $*$ & $*$ & $*$ \\
\hline \multirow{3}{*}{ Training and Education } & $404-1$ & $*$ & $*$ & $*$ & $*$ & $*$ \\
\hline & $404-2$ & $*$ & $*$ & $*$ & $*$ & $*$ \\
\hline & $404-3$ & $*$ & $*$ & $*$ & $*$ & $*$ \\
\hline \multirow{2}{*}{$\begin{array}{l}\text { Diversity and Equal } \\
\text { Opportunity }\end{array}$} & $405-1$ & $*$ & $*$ & $*$ & $*$ & $*$ \\
\hline & $405-2$ & $*$ & $*$ & $*$ & $*$ & $*$ \\
\hline $\begin{array}{l}\text { Equal Remuneration for } \\
\text { Women and Men }\end{array}$ & $406-1$ & NA & $*$ & NA & $*$ & $*$ \\
\hline $\begin{array}{l}\text { Freedom of association } \\
\text { and collective bargaining }\end{array}$ & $407-1$ & $*$ & NA & NA & $*$ & NA \\
\hline Child Labour & $408-1$ & $\begin{array}{l}\text { Out of } \\
\text { scope }\end{array}$ & $*$ & $\begin{array}{l}\text { Out of } \\
\text { scope }\end{array}$ & $*$ & $*$ \\
\hline $\begin{array}{l}\text { Forced or Compulsory } \\
\text { Labour }\end{array}$ & $409-1$ & $\begin{array}{l}\text { Out of } \\
\text { scope }\end{array}$ & $*$ & $\begin{array}{l}\text { Out of } \\
\text { scope }\end{array}$ & $*$ & $*$ \\
\hline Security Practices & $410-1$ & NA & $*$ & $*$ & $*$ & $*$ \\
\hline $\begin{array}{l}\text { Rights of Indigenous } \\
\text { people }\end{array}$ & $411-1$ & NA & NA & NA & $*$ & $*$ \\
\hline \multirow{3}{*}{ Human rights assessment } & $412-1$ & NA & NA & NA & $*$ & $*$ \\
\hline & $412-2$ & NA & NA & NA & $*$ & $*$ \\
\hline & $412-3$ & $*$ & $*$ & $*$ & $*$ & $*$ \\
\hline \multirow{2}{*}{ Local Communities } & $413-1$ & $*$ & $*$ & NA & $*$ & $*$ \\
\hline & $413-2$ & $*$ & $*$ & NA & $*$ & $*$ \\
\hline \multirow[b]{2}{*}{ Supplier social assessment } & $414-1$ & $\begin{array}{l}\text { Out of } \\
\text { scope }\end{array}$ & NA & $*$ & $*$ & $*$ \\
\hline & $414-2$ & $\begin{array}{l}\text { Out of } \\
\text { scope }\end{array}$ & NA & $\begin{array}{l}\text { out of } \\
\text { scope }\end{array}$ & $*$ & $*$ \\
\hline Public Policy & $415-1$ & NA & NA & NA & $*$ & NA \\
\hline \multirow{2}{*}{$\begin{array}{l}\text { Customer health and } \\
\text { safety }\end{array}$} & $416-1$ & $\begin{array}{l}\text { Out of } \\
\text { scope }\end{array}$ & NA & $*$ & $*$ & * \\
\hline & $416-2$ & $\begin{array}{l}\text { Out of } \\
\text { scope }\end{array}$ & NA & $*$ & $*$ & $*$ \\
\hline \multirow{3}{*}{ Marketing and Labelling } & $417-1$ & $*$ & $*$ & NA & $*$ & $*$ \\
\hline & $417-2$ & $*$ & $*$ & NA & $*$ & $*$ \\
\hline & $417-3$ & $*$ & $*$ & NA & $*$ & $*$ \\
\hline Customer privacy & $418-1$ & NA & NA & $*$ & $*$ & $*$ \\
\hline $\begin{array}{l}\text { Socioeconomic } \\
\text { Compliance }\end{array}$ & $419-1$ & NA & NA & $*$ & & $*$ \\
\hline \multicolumn{7}{|c|}{ - Reported and NA : Not available in report } \\
\hline $\begin{array}{l}\text { Retrieval Number: D1029039 } \\
\text { DOI: } 10.35940 / \text { ijitee.D1029. }\end{array}$ & $\begin{array}{l}2020 \odot B E I E S P \\
20\end{array}$ & 183 & $\begin{array}{l}\text { Published By: } \\
\text { Blue Eyes Intelli } \\
\text { \& Sciences Publi }\end{array}$ & $\begin{array}{l}\text { nce Engineering } \\
\text { tion }\end{array}$ & & \\
\hline
\end{tabular}




\section{Environmental Indicators}

There are total 32 standards under eight standards. Please refer to the annexure 2 for GRI standards for the indicators. The environment series starts with 300 and commonly referred as 300 series. The table below depicts the sustainability disclosures for the environmental standards. It has been observed that all the sustainability report disclosed almost all the standards in environmental indicators.

Table Error! No text of specified style in document.: Comparative Analysis of Environmental Indicators

\begin{tabular}{|c|c|c|c|c|c|c|}
\hline $\begin{array}{l}\text { CATEGORY: } \\
\text { ENVIRONMENTAL }\end{array}$ & $\begin{array}{l}300 \\
\text { Series }\end{array}$ & $\begin{array}{c}\text { PVMU } \\
1\end{array}$ & PVMU 2 & $\begin{array}{c}\text { PVMU } \\
\mathbf{3}\end{array}$ & PVMU 4 & $\begin{array}{c}\text { PVMU } \\
5\end{array}$ \\
\hline \multirow{3}{*}{ Materials } & $301-1$ & $*$ & $*$ & $*$ & $*$ & $*$ \\
\hline & $301-2$ & $*$ & $*$ & $*$ & $*$ & $*$ \\
\hline & $301-3$ & $*$ & $*$ & $*$ & $*$ & $*$ \\
\hline \multirow{4}{*}{ Energy } & $302-1$ & $*$ & $*$ & $*$ & $*$ & $*$ \\
\hline & $302-2$ & $*$ & $*$ & $*$ & $*$ & $*$ \\
\hline & 303-3 & $*$ & $*$ & $*$ & $*$ & $*$ \\
\hline & $303-4$ & $*$ & $*$ & $*$ & $*$ & $*$ \\
\hline \multirow{6}{*}{ Water } & $303-5$ & $*$ & $*$ & $*$ & $*$ & $*$ \\
\hline & $303-1$ & $*$ & $*$ & $*$ & $*$ & $*$ \\
\hline & $303-2$ & * & $*$ & $*$ & $*$ & * \\
\hline & $303-3$ & $*$ & $*$ & $*$ & $*$ & $*$ \\
\hline & $303-4$ & NA & NA & $*$ & $*$ & NA \\
\hline & $303-5$ & $\mathrm{NA}$ & NA & $*$ & $*$ & NA \\
\hline \multirow{4}{*}{ Biodiversity } & $304-1$ & $*$ & NA & $*$ & $*$ & $*$ \\
\hline & $304-2$ & $*$ & NA & $*$ & $*$ & $*$ \\
\hline & $304-3$ & $*$ & NA & $*$ & $*$ & $*$ \\
\hline & $304-4$ & $*$ & NA & $*$ & $*$ & $*$ \\
\hline \multirow{7}{*}{ Emissions } & $305-1$ & $*$ & $*$ & $*$ & * & $*$ \\
\hline & $305-2$ & $*$ & $*$ & $*$ & $*$ & $*$ \\
\hline & $305-3$ & $*$ & $*$ & $*$ & $*$ & $*$ \\
\hline & $305-4$ & $*$ & $*$ & $*$ & $*$ & $*$ \\
\hline & $305-5$ & $*$ & $*$ & $*$ & $*$ & $*$ \\
\hline & $305-6$ & $*$ & $*$ & $*$ & $*$ & $*$ \\
\hline & $305-7$ & $*$ & $*$ & $*$ & $*$ & $*$ \\
\hline \multirow{5}{*}{ Effluents and Waste } & $306-1$ & $*$ & $*$ & $*$ & $*$ & $*$ \\
\hline & $306-2$ & $*$ & $*$ & $*$ & $*$ & $*$ \\
\hline & $306-3$ & $*$ & $*$ & $*$ & $*$ & $*$ \\
\hline & $306-4$ & $*$ & $*$ & $*$ & $*$ & $*$ \\
\hline & $306-5$ & $*$ & $*$ & $*$ & $*$ & $*$ \\
\hline Environmental compliance & $307-1$ & $*$ & $*$ & $*$ & $*$ & $*$ \\
\hline \multirow{2}{*}{$\begin{array}{l}\text { Supplier environmental } \\
\text { assessment }\end{array}$} & $308-1$ & $*$ & $*$ & $*$ & $*$ & $*$ \\
\hline & $308-2$ & $*$ & $*$ & $*$ & $*$ & $*$ \\
\hline
\end{tabular}

Reported and NA : Not Available in Report

\section{DISCUSSION}

A detailed analysis of the sustainability reports helped understand the futurist approach of the organization in the study. The organizations were disclosing the sustainability initiatives in the GRI format from 2008. As the concept of sustainability has evolved, the reporting guidelines have also evolved. The sustainability reports of the organization are stakeholder focused. The reports considered for the study have detailed processes and messages for stakeholder engagement. The indigenous organization has a more social aspect of reporting whereas the rest are more environment focused in their reporting. While the indigenous organization is pioneering in corporate social responsibility, the report of the organization does reflect this fact.

The systematic analysis for economic indicators resulted in a few interesting findings. 
The standards like wages and native employment is not reported by most of the organizations. The indirect economic impacts are also not reported by many organizations. One of the reasons can be the late introduction of standards. These standards where introduced in 2015, and the report was prepared in 2016 where the measurement matrix may not be in place. It is a possibility that these indicators will be reported in future reports.

The social indicators comparative analysis concludes that the employee welfare, health \& safety are well reported and documented. Good working condition and responsive welfare policies lowers attrition (Carroll, 1999). The skilled and trained work force helps the organization to bring innovation products and solution. The satisfied employee is the backbone of the organization (Tylor, 1871). The social indicators thus help the organization to report the best human resources management practices. Another aspect of social indicators is society. Most of the organizations are to engage the societal stakeholder in rightful manner. As these standards are linked to SDGs, the organizations started to report the societal standards.

The automobiles manufacturing originations are more concerned towards environment especially with energy, water and waste. Almost all the sustainability reports studied here have adhered to the global standards for the respective environmental indicators. This essentially indicates that the organizations are sensitive towards the environment and a paradigm shift has taken place. The organizations have gone beyond GRI standards reporting and have certified for various other aspects. For example, the organizations in the study are ISO 14000, OSHAS 18001 certified.

The GRI reports analysis for Economic indicators shows that the PVMU 4 is more focused on implementing all the parameters of GRI economic standard. PVMU 1, PVMU 2 and PVMU 3 all lag behind due to few economic indicators. The GRI report analysis for social indicators show very interesting results. PVMU 4 leads in the implementing social indicators and PVMU 1, PVMU2, PVMU3 lag thus clearly showing that industry does not focus more on social aspects. This can be well evidential through the upsurge of social issues like strike and skill shortage in many manufacturing hubs.

PVMU 2 lags in environmental initiatives as per GRI analysis and PVMU 1 leads in environmental analysis. The best practices described in the description of PVMU1 are exceptionally futuristic similarly PVMU 3, PVMU4, PVMU 5 also have environmental initiatives as priority across the globe. The GRI report being represented for the entire organization it is essential that most of the practices mentioned are followed across all locations.

This helps to fulfil the objective of understanding various sustainability initiative taken in the industry and helps to ascertain the major focus of sustainability initiatives. The analysis shows that the industry has many initiatives for environmental sustainability and must work towards holistic sustainability.

\section{CONCLUSION}

The research paper analyses the sustainability reports of organizations in the study. The comparative matrix for the economic, social and environmental indicators shows that organizations are sensitized towards environmental and economic sustainability. The snapshots of the sustainability reports present a committed approach towards sustainability by these organizations. The Indian organization which is one of the biggest passenger vehicle manufacturing organization is inclined towards corporate social responsibility and that is reflected in the report whereas the non-indigenous organization's sustainability reports are having a global outlook.

\section{REFERENCES}

1. Banerjee, S. B. (2001). Managerial Perceptions of Corporate Environmentalism: Interpretations from Industry and Strategic Implications for Organizations. Journal of Management Studies 38(4), 489-513.

2. Bansal, P. (2005). Evolving sustainably: A Longitudinal Study of Corporate Sustainable Development. Strategic Management Journal, 26(3), 197-218.

3. Barbier, E. B. (1987). The Concept of Sustainable Economic Development. Environmental Conservation, 14(2), 101-110.

4. Bell, S., \& Morse, S. (2008). Sustainability Indicators. London: Routledge. , 256.

5. Brammer, S., \& Millington, A. (2008). Does It Pay to Be Different? An Analysis of The

6. Buchholz, R. A., \& Rosenthal, S. B. (2005). Toward A Contemporary Conceptual Framework for Stakeholder Theory. Journal of Business Ethics, 58(1-3), 137-148.

7. Carroll, A. B. (1979). A Three-Dimensional Conceptual Model of Corporate Social Performance. Academy of Management Review, 4(4), 497-505.

8. Carroll, A. B. (1999). Corporate Social Responsibility: Evolution of A Definitional Construct. Business and Society Review, 38(3), 268-295.

9. Cho, C. H., Roberts, R. W., \& Patten, D. M.(2010). The Language of U.S. Corporate

10. Christmann, P., Dey D., \& George, Y. (1999). The Relative Influence of Country Conditions, Industry Structure and Business Strategy on Multinational Corporation Subsidiary Performance, Journal of International Management, 6(4), 241-265.

11. Daly, H. (1987). The Economic Growth Debate: What Some Economists Have Learned but Many Have Not, Journal of Environmental Economics and Management, 14(4), 323-336.

12. Deal, T. E., \& Kennedy, A. A. (1982). Corporate Cultures: The Rites and Rituals of Corporate Life. Reading, Mass., Addison-Wesley Publishing, 238.

13. Dubravka, K. (2017). Sustainability Reporting Quality: The Analysis of Companies in Croatia, Journal of Accounting and Management, 7(1), 1 -14 .

14. Dunphy, D. C., Griffiths, A. \& Benn, S. (2007). Organizational Change for Corporate Sustainability: A Guide for Leaders and Change Agents of the Future. Routledge: London. 324.

15. Dyllick, T., \& Hockerts, K. (2002). Beyond The Business Case for Corporate Sustainability. Business Strategy and the Environment, 11(2), 130-141.

16. Elkington, J. (1997). Cannibals with Forks: The Triple Bottom Line of 21 st Century Business, Oxford: Capstone Buidling, 424.

17. Environmental Disclosure., Accounting, Organizations and Society, 35, 431-443.

18. Environmental Quality Management. Quality Toolbox. 9(3),91-98.

19. Fernandez, E., Junquera, B., \& Ordiz, M. (2003). Organizational Culture and Human Resources in The Environmental Issue: A Review of The Literature. International Journal of Human Resources Management, 14(4), 634-656.

20. Fowler, S. J., \& Hope, C. (2007). Incorporating Sustainable Business Practices into Company Strategy. Business Strategy and the Environment, 16(1), 26-38.

21. Friedman, M. (1970). A Friedman Doctrine: The Social Responsibility of Business Is to Increase Its Profits. The New York Times Magazine, 13(1970), 32-33.

22. Griffiths, A., \& Petrick, J. A. (2001). Corporate architectures for Sustainability. International Journal of Operations and Production Management, 21(12), 1573-1585. 
23. Griffiths, A., \& Zammuto, R. F. (2005). Institutional Governance Systems and Variations in National Competitive Advantage: An Integrative Framework. Academy of Management Review, 30(4), 823-842.

24. Hahn, R., \& Kühnen, M. (2013). Determinants of Sustainability Reporting: A Review of Results, Trends, Theory, and Opportunities In An Expanding Field Of Research. Journal of Cleaner Production, 59, $5-21$.

25. Hahn, R., \& Kühnen, M. (2013). Determinants of Sustainability Reporting: A Review of Results, Trends, Theory, and Opportunities In An Expanding Field Of Research. Journal of Cleaner Production, 59, $5-21$.

26. Hart, S. L. (1997). Beyond Greening: Strategies for A Sustainable World. Harvard Business Review, 75(1), 66-77.

27. Jenkins, R. (2005). Globalization, Corporate Social Responsibility and Poverty. International Affairs, 81(3), 525-540.

28. Johnston, B. R., Hiwasaki, L., Klaver, I. J., Castillo, A. R., \& Strang, V. (Eds.). (2011). Water, Cultural Diversity, and Global Environmental Change: Emerging Trends, Sustainable Futures?. Springer Science and Business Media.

29. Kidd, C. V. (1992). Evolution of Sustainability, Journal of Agriculture and Environmental Ethics, 5(1), 55- 65

30. Laplume, A. O., Sonpar, K., \& Litz, R. A. (2008). Stakeholder Theory: Reviewing A Theory That Moves Us. Journal of Management, 34(6), 1152-1189.

31. Levitt, T. (1958). The Dangers of Social-Responsibility. Harvard business review, 36(5), 41-50.

32. Liverman, D. M., Hanson, M. E., Brown, B. J., \& Merideth, R. W. (1988). Global Sustainability: Toward Measurement. Environmental Management, 12(2), 133-143.

33. Lozano, R., \& Huisingh, D. (2011). Inter-Linking Issues and Dimensions in Sustainability Reporting. Journal of Cleaner Production, 19(2-3), 99-107.

34. Lozano, R., \& Huisingh, D. (2011). Inter-Linking Issues and Dimensions in Sustainability Reporting. Journal of Cleaner Production, 19(2-3), 99-107.

35. Morelli, J. (2011). Environmental Sustainability: A Definition for Environmental Professionals, Journal of Environmental Sustainability: 1(1), 2. DOI: $10.14448 /$ jes.01.0002 Available at: http://scholarworks.rit.edu/jes/vol1/iss1/2 Accessed on 24th Jun 2015.

36. Percy, S. W. (2000). Environmental sustainability and corporate strategy: Why a firm's Chief Environmental Officer should be its CEO Corporate Environmental Strategy, 7, 195-202.

37. Peteraf, M. A. (1993). The Cornerstones of Competitive Advantage: a resource-based view. Strategic Management Journal 14(3), 179-191.

38. Pojasek, R. (2000). Striving for Environmental Excellence with The Baldrige Model.

39. Porter, M. E. (1985). Competitive Advantage: Creating and Sustaining Superior Performance. Free Press: New York; Collier Macmillan: London., 487.

40. Post, J. E., Altman, B. W. (1994). Managing The Environmental Change Process: Barriers and Opportunities. Journal of Organizational Change Management 7(4), 64-81.

41. Preston, L. E. (1985). Research in Corporate Social Performance and Policy. JAI Press: Greenwich, CT. Psychology, 22, 245-285. New York: Academic Press.

42. Relationship Between Corporate Social and Financial Performance. Strategic Management Journal, 29(12), 1325-1343.

43. Riordan, M., Vandenberg, R. \& Richardson, H. (2005). Employee Involvement Climate and Organizational Effectiveness. Human Resource Management. 44(4), 471-488

44. Shadur, M. A., Kienzle, R., \& Rodwell, J. J. (1999). The Relationship between Organizational Climate and Employee Perceptions of Involvement. Group and Organization Management, 24(4), 478-503.

45. Sharma, S. (2003). Research in Corporate Sustainability: What Really Matters? In Research in Corporate Sustainability: The Evolving Theory and Practice of Organizations in the Natural Environment, Sharma S, Starik M (eds). Elgar: Cheltenham, 1-29.

46. Sharma, S., Starik, M., \& Husted, B. (2007). Organizations and the Sustainability Mosaic, Crafting Long-Term Ecological and Societal Solutions, Edward Elgar Publishing, 328.

47. Shrivastava, P. (1995). The Role of Corporations in Achieving Ecological Sustainability, Academy of Management Review,20(4) 936-960.

48. Starik, M., \& Rands, G. (1995). Weaving an Integrated Web: Multilevel and Multisystem Perspectives of Ecologically Sustainable Organizations. The Academy of Management Review. 20(4), 908-935

49. Steimle, U., \& Zink, K. J. (2006). Sustainable Development and Human Factors" in Karnowski, W. (ed.), International Encyclopaedia of Economics and Human Factors, 2, London: Taylor \& Francis, 325.
50. Tylor, E. B. (1871). Primitive Culture: Researches into the Development of Mythology, Philosophy, Religion, Language, Art and Custom, London, J. Murray, 500.

51. White, M. A. (1996). Corporate Environmental Performance and Shareholder Value, Working Paper WHI002. University of Virginia, Charlottesville, McIntire School of Commerce.

52. Winn, M. I., \& Kirchgeorg, M. (2005). The Siesta Is Over: A Rude Awakening from Sustainability Myopia. In Corporate Environmental Strategy and Competitive Advantage, Sharma S, Aragón-Correa JA (eds). Elgar: Cheltenham, UK, 232-258.

\section{AUTHOR PROFILE}

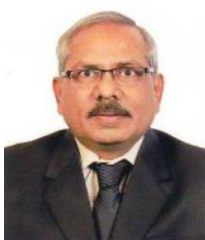

Dr. Chandrakant Rawal had the leadership traits in him even three decades agowhen he made his humble beginnings in academics. In subsequent phase of career, he served for eighteen long years as a principal of 3 institutes. During this tenure his exceptional leadership qualities and skills were in full display. TheAward was sweetened further with the college magazine being declared as the "BestMagazine" successively for three years. The crowning glory was the Best Principal

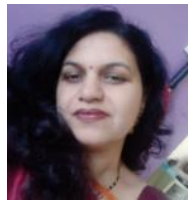

Dr. Shilpa Jitendra Kulkarni has more than 20 years of experience in Academia and industry. Shilpa has worked with conglomerates like Mahindra and Mahindra, GMR,First American in Human resource side of the business. It was her passion for teaching brought her to academics. She has worked with esteemed universities like ICFAI, Christ university, Symbiosis university and Savitribai Phule Pune University. She is certified GRI auditor and also works as sustainability expert in human capital management with Maratha Chamber of Commerce, Industries and Agriculture (MCCIA).Cuurenlty she is working with $\mathrm{BMCC}$ as research coordinator. 